\title{
The sodium requirements of growing steers given an all-sorghum grain ration
}

\author{
By J. G. MORRIS \\ Department of Animal Science, University of California, Davis, \\ California $956 \mathrm{16}$, USA \\ AND R. J. W. GAR'TNER \\ Animal Research Institute, Yeerongpilly, Brisbane, Australia
}

(Received I3 January 1970-Accepted 8 August 1970)

\begin{abstract}
I. Eight groups, each of five steers, were given a basal ration of sorghum grain plus urea and minerals $(0.003 \%$ sodium) ad lib. and demineralized water. Two groups, one given coarsely rolled and the other finely ground grain, were given the basal ration alone or the basal ration supplemented with $3.25,6.50$ or $13.0 \mathrm{~g} \mathrm{Na}$ /animal daily as $\mathrm{NaHCO}_{3}$. Mean daily intakes of Na per animal for each of the four treatments were $133 \mathrm{mg}, 3 \cdot \mathrm{I}, 6 \cdot 0$ and I I.4 g, respectively.

2. The mean growth rate of steers given the basal ration was $0.59 \mathrm{~kg} / \mathrm{d}$, which was significantly less than that of steers ingesting $3.1 \mathrm{~g} \mathrm{Na} / \mathrm{d}(0.93 \mathrm{~kg} / \mathrm{d})$. There were no significant differences in the growth rates of steers ingesting $3 \cdot 1,6.0$ and $1 \mathrm{I}^{\cdot 4} \mathrm{~g} \mathrm{Na} / \mathrm{d}$.

3. The concentration of $\mathrm{Na}$ in the saliva from the steers fed on the basal ration was significantly less and the concentration of potassium significantly greater than those from steers with $\mathrm{Na}$ intakes of $3 \cdot \mathrm{I} \mathrm{g}$ or more per $\mathrm{d}$. The mean $\mathrm{Na}: \mathrm{K}$ ratio of the saliva from steers given the basal ration was less than unity, whereas the ratio in the saliva from steers ingesting $3 \cdot 1 \mathrm{~g}$ or more $\mathrm{Na} / \mathrm{d}$ varied between $\mathrm{I}$ I and $2 \mathrm{I}$.

4. The concentrations of $\mathrm{Na}$ in the ruminal fluid were significantly less in steers given the basal ration than in those ingesting $3 . \mathrm{I} g$ or more $\mathrm{Na} / \mathrm{d}$.

5. The widths of the cortex and the zona glomerulosa as a percentage of the adrenal cortex were significantly greater in steers given the basal ration only than in those given $\mathrm{Na}$ intakes of $3 . \mathrm{I} / \mathrm{d}$. There were no significant differences in the width of the zona glomerulosa of the adrenals from steers ingesting $3 \cdot \mathrm{I}, 6 \cdot 0$ or $\mathrm{II} \cdot 4 \mathrm{~g} \mathrm{Na} / \mathrm{d}$.

6. A Na and $\mathrm{K}$ balance conducted on two steers given the basal ration only for a further I I $2 \mathrm{~d}$ after the other steers were slaughtered indicated that faecal and urinary $\mathrm{Na}$ losses approximated to the $\mathrm{Na}$ intake, but there was a positive $\mathrm{K}$ balance. When these steers were subsequently given a supplement of $380 \mathrm{~m}$-equiv. $\mathrm{Na} / \mathrm{d}$ for $\mathrm{I} 6 \mathrm{~d}$ they retained $370 \mathrm{~m}$-equiv. $\mathrm{Na} / \mathrm{d}$ and were in negative $\mathrm{K}$ balance.

7. It is suggested that the value given by the Agricultural Research Council (1965) for the $\mathrm{Na}$ requirement of steers for growth is excessive.

8. Steers given coarsely rolled grain ate significantly more feed per $\mathbf{d}$ than those given finely ground grain, but rate of body-weight gain was not affected by the method of grain processing.
\end{abstract}

The requirements of cattle for supplemental salt have been investigated sporadically by a number of workers since Boussingault ( 1847 ) published the results of his observations. Babcock's (1905) classical studies confirmed Boussingault's observations, and later Aines \& Smith (1957) demonstrated that the response to salt was due to sodium rather than to chloride.

The Agricultural Research Council (1965) has calculated the requirements for growth of cattle on the basis of accretion of $\mathrm{Na}$ during growth (from values for body composition) and losses of $\mathrm{Na}$ which occur in the faeces and urine. However, to our knowledge, there has been only one actual trial from which an estimate of the $\mathrm{Na}$ requirements of cattle for growth can be derived. Theiler, Green \& Du Toit (I927) added $\mathrm{Na}$ at a single level to a feed low in $\mathrm{Na}$ and noted that growth of two heifers was not limited, but fertility may have been, by the intake of only $1.5 \mathrm{~g} \mathrm{Na} / \mathrm{d}$. 
This paper reports the effect of the addition of $\mathrm{Na}$ (as bicarbonate) at three levels to an all-sorghum grain ration on the growth rate, feed intake, $\mathrm{Na}$ and $\mathrm{K}$ contents of saliva, plasma, urine and faeces, and on the weight and histological picture of the adrenal and salivary glands of growing steers. The three amounts of $\mathrm{Na}$ added were $0.5,1.0$ and 2.0 times the Agricultural Research Council's estimated requirement for cattle of $300 \mathrm{~kg}$ gaining I kg body-weight $/ \mathrm{d}$.

\section{EXPERIMENTAL}

\section{Animals}

Forty grade Hereford steers, about 15 months of age and without permanent incisor teeth, were selected on a commercial beef cattle property in south-eastern Queensland for uniformity of body-weight. They were transported to the Husbandry Research Farm, Rocklea, where they underwent the inoculations and passed the health tests described by Morris \& Pepper (I969). On two occasions, once when the steers were first brought into the concreted yards and again 3 weeks later, they were all drenched with $20 \mathrm{~g}$ thiabendazole/head.

\section{Feed}

Oaten chaff was made from a crop of Avena $c v$. Saia cut for hay when the grain was in the hard dough stage ( $140 \mathrm{~d}$ after planting). It was stored under cover for about 30 months after it was harvested, then chaffed to a mean length of $1.25 \mathrm{~cm}$ before it was offered to the steers. Bulk grain, low in $\mathrm{Na}$ and from hybrid varieties of Sorghum vulgare, was purchased from a commercial supplier. It was prepared either by coarse rolling in a mill set just to fracture the grain or by fine grinding in a hammer mill fitted with a screen with $6 \mathrm{~mm}$ apertures.

Each $1000 \mathrm{~kg}$ of sorghum grain mixture contained: $964 \mathrm{~kg}$ sorghum grain, $20 \mathrm{~kg}$ urea, $8.7 \mathrm{~kg}$ calcium hydroxide, $2 \cdot 4 \mathrm{~kg}$ calcium sulphate, $2 \cdot 37 \mathrm{~kg}$ ammonium chloride, I. $54 \mathrm{~kg}$ magnesium oxide, 3 I $4 \mathrm{~g}$ zinc sulphate, I Io g manganese sulphate, 32 g copper sulphate, $5^{\circ} 7 \mathrm{~g}$ cobalt chloride and $4.9 \times 10^{6}$ i.u. stabilized vitamin A (Rovimix A-325; Roche Products (Australia) Ltd).

The proximate analyses of the grain and oaten chaff and the mechanical analyses of the grain are presented in Tables $\mathbf{I}$ and 2 .

\section{Design}

$\mathrm{A}_{4} \times 2$ factorial experiment was used to investigate the effects of three levels of $\mathrm{Na}$ supplementation on the growth rate and $\mathrm{Na}$ metabolism of steers fed on an allsorghum grain ration (basal) and the effect of coarse $v$. fine grinding of the grain on feed utilization. The levels of $\mathrm{Na}$ in the four diets were: basal $(0.003 \% \mathrm{Na}$ in the ration), basal $+3.25 \mathrm{~g}$, basal $+6 \cdot 5 \circ \mathrm{g}$, basal $+\mathrm{I}_{3} \cdot \mathrm{O} \mathrm{g} \mathrm{Na}$ per animal per $\mathrm{d}$.

The forty steers were allocated to eight blocks, each of five steers of similar bodyweight, and were then randomly allocated to the treatments within each block. With the exception of two steers from the basal group, the steers kept in yards were slaughtered after a mean experimental period of $\mathrm{r} 66 \pm \mathrm{I} \mathrm{d}$.

The two steers retained were given the basal ration in metabolism crates for a further 
period of $\mathrm{I} 2 \mathrm{~d}$ to determine the effects of a prolonged period of $\mathrm{Na}$ deprivation. $\mathrm{A} \mathrm{Na}$ and $\mathrm{K}$ balance was then conducted on the two steers during three periods each of 14 , IO and $2 \mathrm{I} \mathrm{d}$ during the last $95 \mathrm{~d}$ in the metabolism crates. At the conclusion of these measurements, $380 \mathrm{~m}$-equiv. $\mathrm{Na}$ as sodium chloride were given daily to each steer and a further balance measurement was undertaken over a $16 \mathrm{~d}$ period.

Table I. Composition of the oaten chaff and sorghum grain after the addition of urea and minerals

\begin{tabular}{|c|c|c|c|c|c|c|c|}
\hline \multirow[b]{2}{*}{ Fodder } & \multicolumn{7}{|c|}{ Percentage composition (dry-matter basis) } \\
\hline & $\mathbf{N}$ & Ash & $\mathbf{P}$ & $\mathrm{Ca}$ & $\mathrm{Na}$ & $\mathrm{K}$ & $\mathrm{Cl}$ \\
\hline $\begin{array}{l}\text { Oaten chaff } \\
\text { Sorghum grain }\end{array}$ & $\begin{array}{l}2 \cdot 0 \\
2.8\end{array}$ & $\begin{array}{r}10 \cdot 6 \\
2 \cdot 6\end{array}$ & $\begin{array}{l}0.30 \\
0.32\end{array}$ & $\begin{array}{l}0.33 \\
0.48\end{array}$ & $\begin{array}{l}1.190 \\
0.003\end{array}$ & $\begin{array}{l}I \cdot 45 \\
0.25\end{array}$ & \\
\hline
\end{tabular}

Table 2. Mechanical analysis of the sorghum grain expressed as a percentage of each size range

$\begin{array}{ccc}\text { Size range (mm) } & \text { Coarse rolled } & \text { Fine milled } \\ \text { Greater than 2.5 } & 5 \cdot 8 & 0 \cdot 7 \\ 2 \cdot 25-2 \cdot 50 & 2 \cdot 4 & 0 \cdot 2 \\ 2 \cdot 00-2 \cdot 25 & 18 \cdot 9 & 2 \cdot 1 \\ 1 \cdot 75-2 \cdot 00 & 16 \cdot 6 & 3 \cdot 0 \\ 1 \cdot 50-1 \cdot 75 & 17 \cdot 6 & 6 \cdot 6 \\ 1 \cdot 25-1 \cdot 50 & 18 \cdot 6 & 18 \cdot 6 \\ 0 \cdot 50-1 \cdot 25 & 13 \cdot 7 & 46 \cdot 3 \\ 0 \cdot 25-0.50 & 2 \cdot 2 & 8 \cdot 3 \\ \text { Less than } 0 \cdot 25 & 4 \cdot 2 & 14 \cdot 2\end{array}$

Feeding schedule

All groups of steers were offered for the first $6 \mathrm{~d}$ a ration of $4 \mathrm{~kg}$ oaten chaff plus $4 \mathrm{~kg}$

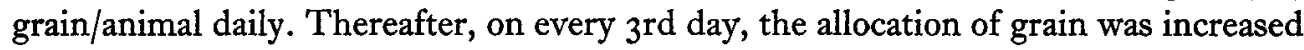
by $0.5 \mathrm{~kg} /$ animal daily and the roughage decreased until the steers were given on the 28th day an all-grain ration which thereafter was given $a d$ lib.

Steers received water from the Brisbane city supply (about $0.004 \% \mathrm{Na}$ ) until the 27 th day. Thereafter, they were given demineralized water (less than $0.0001 \% \mathrm{Na}$ ) ad lib.

The supplements of $\mathrm{Na}$ were supplied as $\mathrm{NaHCO}_{3}$-grain premixes, at the rate of $200 \mathrm{~g} /$ animal daily. To bind the bicarbonate to the grain, $8 \%$ linseed oil was added.

\section{Measurements}

Body-weight and carcass weight gain. The steers were weighed after being without feed for $24 \mathrm{~h}$ and water for $12 \mathrm{~h}$ (fasted body-weight) both before entering the experiment and $24 \mathrm{~h}$ before slaughter. At weekly intervals body-weight was recorded without water or food restriction (non-fasted body-weight).

Carcass weight gain was calculated for individual steers as the difference between the final hot carcass weight and the initial fasted body-weight multiplied by a dressing percentage of $49^{\circ} 9$ (Morris \& O'Bryan, 1965).

Feed and water intake. Residues of uneaten feed were removed at weekly intervals from the feed troughs and weighed, and a proportional sample was bulked for analysis 
for $\mathrm{Na}$. The intake of water by the steers was measured at daily intervals during two periods (the 88th to the Ioznd and the I I 3 th to the I23rd day inclusive) of all-grain feeding. The results for feed and water intake were analysed for the effects of $\mathrm{Na}$ levels, coarsely rolled $v$. finely ground grain and periods (weeks).

Saliva. Samples of saliva were collected and analysed from each steer receiving either the basal diet or the basal diet supplemented with $3.25 \mathrm{~g} \mathrm{Na} / \mathrm{d}$, on the 56 th day of all-grain feeding and thereafter from all groups at intervals of either 14 or $28 \mathrm{~d}$. On each occasion three samples of mixed saliva were collected from the region of the papilla parotidea into a short length of stainless-steel tubing connected to clear plastic and glass tubing and an aspirator bulb and analysed for $\mathrm{Na}$ and $\mathrm{K}$.

Blood. Samples of blood were collected by venepuncture at $14 \mathrm{~d}$ intervals after the steers first received the all-grain ration, and the plasma $\mathrm{Cl}$, the $\mathrm{Na}$ and $\mathrm{K}$ concentrations in the plasma and erythrocytes, the packed cell volume, haemoglobin, red cell count and the inorganic phosphorus and urea concentrations of the whole blood were determined.

Urine, faeces and ruminal fluid. Samples of urine and faeces were collected from steers on each of 3 consecutive days preceding the measurement of fasted body-weight before slaughter. Ruminal fluid collected at slaughter was centrifuged and the supernatant fraction was analysed for $\mathrm{Na}$ and $\mathrm{K}$.

Extracellular fluid volumes. The extracellular fluid volumes (ECFV) of steers given the basal diet and basal diet supplemented with $6.5 \mathrm{~g} \mathrm{Na} / \mathrm{d}$ were measured about I week before slaughter by the dilution of sodium thiocyanate. Each animal received $50 \mathrm{ml}$ of a $10 \%$ solution of sodium thiocyanate intravenously. The concentrations of thiocyanate were measured in the plasma before injection and at 2,3 and $4 \mathrm{~h}$ after injection.

Organs and glands. At slaughter, the liver, kidneys, parotid salivary glands and adrenals were collected and weighed. Tissue from the caudate lobe of the liver was analysed for vitamin A. Blocks of kidney and parotid salivary tissue were fixed in a I0 \% buffered neutral formalin, embedded in paraffin, then sectioned $(6 \mu \mathrm{m}$ thickness), and the sections were stained with haematoxylin and eosin preparatory to histological examination.

The left and right adrenal glands were cut in the medial plane to aid fixation in formalin and then sectioned and stained with haematoxylin and eosin. Photographic prints were made of the sections by projection through a Leitz Focomat IC enlarger and the widths of the zona glomerulosa and cortex in the resulting prints were measured in five randomly selected places by two operators.

\section{Analytical methods}

The analytical methods employed were as follows: $\mathrm{Na}$ and $\mathrm{K}$ concentrations in the saliva, blood, plasma, urine and ruminal fluid were estimated by flame photometry in an Instrumentation Laboratories flame photometer model I43. Samples were diluted $\mathrm{I}$ in 200 with a solution of lithium chloride ( $5 \mathrm{~m}$-equiv. $/ 1$ ) containing $0.02 \%$ Tween 80 before analysis. Plasma samples for the estimation of $\mathrm{Na}$ and $\mathrm{K}$ were prepared by centrifugation of whole blood within $30 \mathrm{~min}$ of withdrawal. $\mathrm{Plasma} \mathrm{Cl}$ was 
determined with a EEL chloride meter (Evans Electroselenium Ltd, Halstead, Essex). Plasma thiocyanate was measured by the method of Bowler (1944). Inorganic phosphorus and urea concentrations in the blood were determined by the methods of Moir (1954) and of Levine, Leon \& Steigmann (196r), respectively. Haemoglobin was determined by the method of Donaldson, Sisson, King, Wootton \& Macfarlane (195I), packed cell volume by the microhaematocrit method using a relative centrifugal force of about $7200 \mathrm{~g}$ for $8 \mathrm{~min}$, and erythrocyte count in an automatic cell counter (Celloscope IOr; AB Lars Ljunberg and Co., Gyllenstiernsgatan r8, Stockholm NO, Sweden). Erythrocyte $\mathrm{Na}$ and $\mathrm{K}$ concentrations were calculated by difference, using the respective concentration for blood and plasma and the packed cell volume.

The feeds were analysed for their proximate constitutents by the methods of the Association of Official Agricultural Chemists (1960) with the modifications described by Morris \& Gartner (1967). The $\mathrm{Na}, \mathrm{K}$ and $\mathrm{Cl}$ concentrations in the grain and the $\mathrm{Na}$ and $\mathrm{K}$ concentrations in faeces were measured by the methods described by Gartner $\&$ Twist (1968). The vitamin A concentration in samples of liver was measured by the macro-method of Gartner \& Ryley (1956).

In the analysis of the results, missing values were estimated by analysis of covariance; for each missing value a dummy covariate was used. This method provides unbiased tests for treatment effects (Conns, 1957).

\section{RESULTS}

Health of the steers. No adverse clinical signs, other than occasional bloating, were observed in the steers. One steer from the group given finely ground grain and $\mathrm{r} 3^{\circ} \circ \mathrm{g} \mathrm{Na} / \mathrm{d}$ exhibited anorexia and stranguria after $70 \mathrm{~d}$ of all-grain feeding. Clinical examination indicated an obstruction of the urethra. The steer was slaughtered and numerous calculi were found in the hilus of the kidneys and in the bladder, and pasty material occluded the urethra at the sigmoid flexure. The calculi and material from the urethra were mainly composed of magnesium ammonium phosphate.

Onesteer from the group given coarsely rolled grain and $6.5 \mathrm{~g} \mathrm{Na} / \mathrm{d}$ had a slow rate of body-weight gain $(0.43 \mathrm{~kg} / \mathrm{d})$ and a profuse nasal discharge. Clinical examination of this steer suggested that a viral infection may have been responsible for the latter condition, so the animal was slaughtered at $\mathrm{x} 47 \mathrm{~d}$. However, no viruses were isolated from the respiratory tract. Missing values for these two animals were calculated and used in the analysis of the results.

Net intakes of $N a$. Total feed residue amounted to a mean $( \pm \mathrm{SD})$ of $6.0 \pm \mathrm{I} \%$ of the grain mixture given to the eight groups. The grain residues from all groups had a higher percentage of ash and contained more $\mathrm{Na}$ than the grain mixture that was offered.

The mean net daily intakes of $\mathrm{Na}$ calculated from the $\mathrm{Na}$ content of the feed, the $\mathrm{NaHCO}_{3}$ supplement and the residues were $133 \mathrm{mg}$ for the basal groups, and $3 \cdot \mathrm{I}$, 6.0 and $11.4 \mathrm{~g}$ for the groups given $3.25,6.5$ and $13.0 \mathrm{~g}$ Na respectively.

Feed intake. Steers given the basal diet ate significantly less feed $(P<0.01)$ than those ingesting either $3 . \mathrm{I}, 6 \cdot 0$ or $\mathrm{II}_{4} \mathrm{~g} \mathrm{Na}$ /animal daily. There were significant 


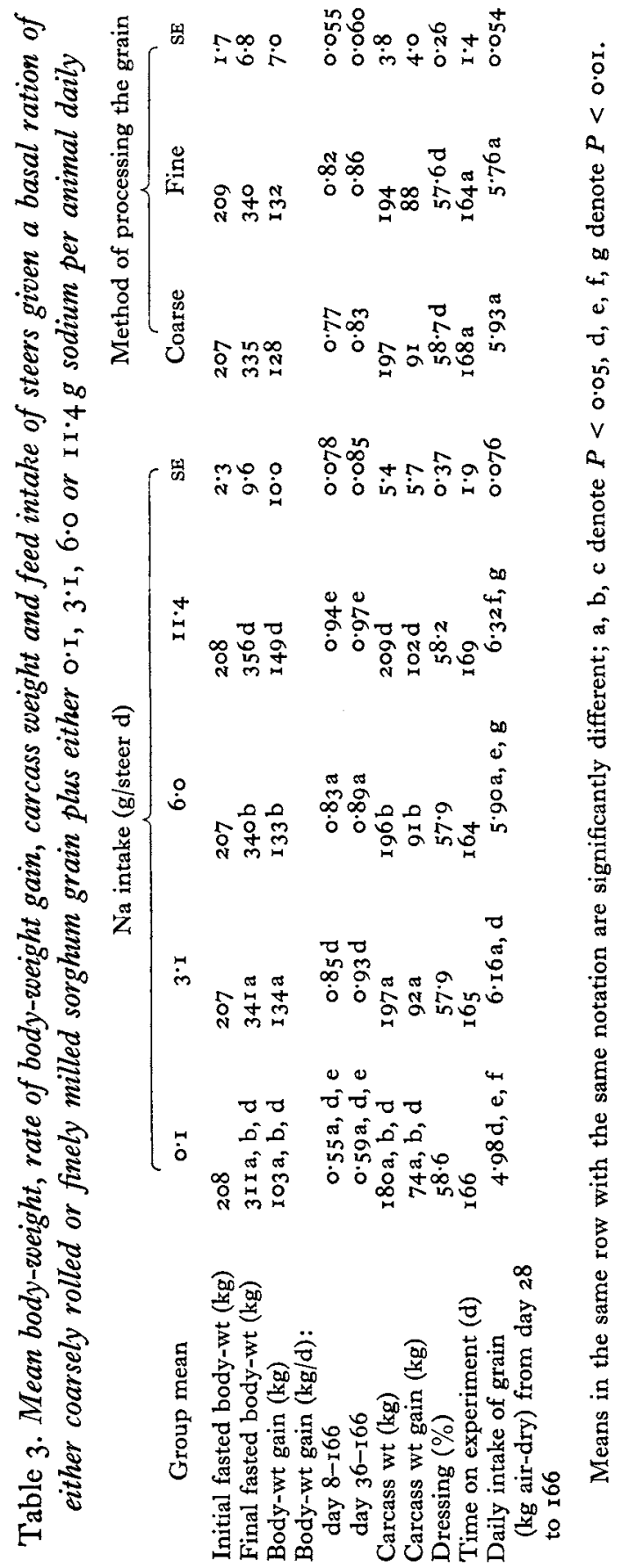


differences in feed intake due to the three levels of Na supplementation, but not between $3 \cdot \mathrm{I}$ and $\mathrm{I}_{\mathrm{I}} \cdot 4 \mathrm{~g} / \mathrm{d}$. Steers given coarsely rolled grain had a significantly greater $(P<0.05)$ daily feed intake than those given finely milled grain (Table 3$)$.

Intake of water. Neither the level of $\mathrm{Na}$ in the ration nor the method of processing the grain had a significant effect on the group mean daily intake of water. However, the interaction of level of $\mathrm{Na}$ intake $\times$ grain type was significant $(P<0.05)$ when tested against the period $\times$ interaction term. The intake of water was not significantly different for the two periods (20.0 v. 19.9; $\mathrm{SE} \pm 0.531$ /steer per d).

Body-weight gain. The initial and final fasted body-weights and body-weight gains for the steers are presented in Table 3 . The $b$ values of linear regressions of non-fasted body-weight on time for each individual steer were used in the analysis of rate of body-weight gain. The daily body-weight gain of steers given the basal ration was significantly less than that of steers ingesting $3^{\circ} \mathrm{I}, 6 \cdot 0$ or $1 \mathrm{I}^{\cdot} \cdot \mathrm{g} \mathrm{Na}^{\mathrm{g}} \mathrm{\textrm {animal }}$ daily (Table 3). Differences in rate of gain were significant both for the period of all-grain feeding (days 36-166) and for the total period of yard feeding (days 8-166).

There was no significant effect of method of grain preparation on either daily rate of body-weight gain or efficiency of feed conversion.

Carcass weight. The carcasses from the steers given the basal diet were significantly lighter in weight and the calculated carcass weight gains were significantly less than those of steers ingesting $3 \cdot \mathrm{I}, 6 \cdot 0$ or II $4 \mathrm{~g} \mathrm{Na}$ /animal daily (Table 3 ).

There were no significant differences between the dressing percentages of steers given the basal ration with or without added $\mathrm{Na}$, but steers fed on coarsely rolled grain had a significantly greater dressing percentage than steers fed on finely milled grain.

Saliva. In the analysis of the effects of the $\mathrm{Na}$ treatments on the concentration of $\mathrm{Na}$ and the $\mathrm{Na}: \mathrm{K}$ ratio in the saliva, it was found that the variances of the values from the basal group were greater than those from the three groups given Na supplements. Therefore one error was used to test the values for groups receiving $0 \cdot I v \cdot 3 \cdot I, 6 \cdot 0$ and II.4 $\mathrm{g} \mathrm{Na}$ and another error for testing the groups $3 . \mathrm{I} v .6 \cdot 0 v$. II.4 $\mathrm{g} \mathrm{Na}$. The standard deviations of the treatment means for the concentration of $\mathrm{K}$ in the saliva were proportional to the mean; a logarithmetic transformation of the concentrations of $\mathrm{K}$ stabilized the variances and was used in the analysis of the results.

The mean concentrations of $\mathrm{Na}$ and $\mathrm{K}$, and $\mathrm{Na}$ plus $\mathrm{K}$, and the $\mathrm{Na}: \mathrm{K}$ ratio in the saliva from the steers at each of the five sampling dates are shown in Table 4. The saliva from steers given the basal ration had a significantly lower concentration of $\mathrm{Na}$ and a significantly higher concentration of $\mathrm{K}$, and hence a lower $\mathrm{Na}: \mathrm{K}$ ratio, than that from steers ingesting either $3 \cdot 1,6 \cdot 0$ or $\mathrm{II}^{\circ} 4 \mathrm{~g} \mathrm{Na}$ per $\mathrm{d}$. The ratio of $\mathrm{Na}$ to $\mathrm{K}$ in the saliva of steers given the basal diet did not change substantially between days $5^{6}$ and 140.

Although there was a markedly lower concentration of $\mathrm{Na}$ in the saliva from steers given the basal ration only, because of the higher concentrations of $K$ the sum of the concentrations of $\mathrm{Na}+\mathrm{K}$ was significantly less than that of steers receiving supplements of $\mathrm{Na}$ on only three of the five sampling dates.

Ruminal fluid. A log transformation was used in the analysis of the $\mathrm{Na}$ and $\mathrm{K}$ 
concentrations and $\mathrm{Na}: \mathrm{K}$ ratio. The concentration of $\mathrm{Na}$ and the ratio of $\mathrm{Na}: \mathrm{K}$ were significantly less and the concentration of $\mathrm{K}$ was significantly greater in the fluid collected at slaughter from the rumens of steers given the basal ration only than in that from the steers given supplements of $\mathrm{Na}$ (Table 5).

Table 4. Arithmetic mean of the concentrations of sodium and sodium plus potassium (m-equiv. $/ l$ ) and the $N a: K$ ratio and the geometric mean concentration of $K$ of saliva from steers given a basal ration of sorghum grain plus either $0 \cdot 1,3 \cdot I, 6 \cdot 0$ or I I 4.4 Naper $d$

\begin{tabular}{|c|c|c|c|c|c|c|}
\hline \multirow{2}{*}{$\begin{array}{l}\text { Days of } \\
\text { all-grain } \\
\text { feeding }\end{array}$} & \multirow[b]{2}{*}{ Ion } & \multicolumn{4}{|c|}{ Na intake $(\mathrm{g} / \mathrm{d})$} & \multirow[b]{2}{*}{ SE } \\
\hline & & 0.1 & $3 \cdot I$ & 6.0 & I I 4 & \\
\hline $5^{6}$ & $\begin{array}{c}\mathrm{Na} \\
\mathrm{K} \\
\mathrm{Na}+\mathrm{K} \\
\mathrm{Na}: \mathrm{K}\end{array}$ & $\begin{array}{l}62.9 \mathrm{~d} \\
64.5 \mathrm{~d} \\
135.7 \dagger \\
1.59 \mathrm{~d}\end{array}$ & $\begin{array}{r}132 \cdot 3 \mathrm{~d} \\
12 \cdot 2 \mathrm{~d} \\
146 \cdot 3 \\
12 \cdot 5 \mathrm{~d}\end{array}$ & - & - & $\begin{array}{l}(8 \cdot 5)^{*} \\
2 \mathrm{I} \cdot 6 \dagger \\
4 \cdot 1 \\
1 \cdot 6\end{array}$ \\
\hline 70 & $\begin{array}{c}\mathrm{Na} \\
\mathrm{K} \\
\mathrm{Na}+\mathrm{K} \\
\mathrm{Na}: \mathrm{K}\end{array}$ & $\begin{array}{r}52 \cdot 7 \mathrm{~d}, \mathrm{e}, \mathrm{f} \\
69 \cdot 5 \mathrm{~d}, \mathrm{e}, \mathrm{f} \\
\mathrm{I28} \cdot 5 \mathrm{~d}, \mathrm{e}, \mathrm{f} \\
\mathrm{r} \cdot 24 \mathrm{~d}, \mathrm{e}, \mathrm{f}\end{array}$ & $\begin{array}{l}\mathrm{r} 39 \cdot 1 \mathrm{~d} \\
8 \cdot 9 \mathrm{~d} \\
148 \cdot 2 \mathrm{~d} \\
16 \cdot 2 \mathrm{a}, \mathrm{d}\end{array}$ & $\begin{array}{c}146 \cdot 6 \mathrm{e} \\
7 \cdot 4 \mathrm{e} \\
154.4 \mathrm{e} \\
20 \cdot 6 \mathrm{a}, \mathrm{b}, \mathrm{e}\end{array}$ & $\begin{array}{c}\mathrm{r} 4 \mathrm{I} \cdot 7 \mathrm{f} \\
8 \cdot 9 \mathrm{f} \\
\mathrm{I} 50 \cdot 2 \mathrm{f} \\
\mathrm{I} 6 \cdot \mathrm{Ib}, \mathrm{f}\end{array}$ & $\begin{array}{l}(7 \cdot 6) * 3 \cdot 0 \\
10 \cdot 9 \dagger \\
3 \cdot 0 \\
1 \cdot 2\end{array}$ \\
\hline 98 & $\begin{array}{c}\mathrm{Na} \\
\mathrm{K} \\
\mathrm{Na}+\mathrm{K} \\
\mathrm{Na}: \mathrm{K}\end{array}$ & 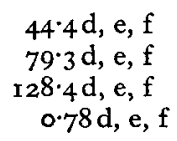 & $\begin{array}{r}135.5 \mathrm{~d} \\
10.8 \mathrm{~d} \\
147.8 \mathrm{~d} \\
14.5 \mathrm{~d}\end{array}$ & $\begin{array}{r}\mathrm{I} 37.8 \mathrm{e} \\
9.6 \mathrm{e} \\
\text { I } 48.9 \mathrm{e} \\
\text { I6.0e }\end{array}$ & $\begin{array}{r}145 . \mathrm{ff} \\
8.4 \mathrm{f} \\
153^{\circ} .6 \mathrm{f} \\
17.9 \mathrm{f}\end{array}$ & $\begin{array}{l}(8.4)^{*} 4.7 \\
13.7 \dagger \\
2.7 \\
1.5\end{array}$ \\
\hline 126 & $\begin{array}{c}\mathrm{Na} \\
\mathrm{K} \\
\mathrm{Na}+\mathrm{K} \\
\mathrm{Na}: \mathrm{K}\end{array}$ & $\begin{array}{l}70.5 \mathrm{~d}, \mathrm{e}, \mathrm{f} \\
58 \cdot 4 \mathrm{~d}, \mathrm{e}, \mathrm{f} \\
143 \cdot \mathrm{I} \\
2 \cdot 32 \mathrm{~d}, \mathrm{e}, \mathrm{f}\end{array}$ & $\begin{array}{c}137 \cdot 4 \mathrm{~d} \\
9 \cdot 5 \mathrm{~d} \\
148 \cdot 2 \\
15 \cdot 6 \mathrm{~d}, \mathrm{~g}\end{array}$ & $\begin{array}{l}\text { I } 43.0 \mathrm{e} \\
7.2 \mathrm{e} \\
\text { I } 50.9 \\
20.5 \mathrm{a}, \mathrm{e}, \mathrm{g}\end{array}$ & $\begin{array}{l}14 \mathrm{I} \cdot 9 \mathrm{f} \\
8 \cdot 9 \mathrm{f} \\
15 \mathrm{r} \cdot 8 \\
16 \cdot 5 \mathrm{a}, \mathrm{f}\end{array}$ & $\begin{array}{l}(5 \cdot 3) * 1 \cdot 8 \\
15 \cdot 3 \dagger \\
3 \cdot 1 \\
1 \cdot 2\end{array}$ \\
\hline$x_{40}$ & $\begin{array}{c}\mathrm{Na} \\
\mathrm{K} \\
\mathrm{Na}+\mathrm{K} \\
\mathrm{Na}: \mathrm{K}\end{array}$ & $\begin{array}{l}60.4 \mathrm{~d}, \mathrm{e}, \mathrm{f} \\
80.8 \mathrm{~d}, \mathrm{e}, \mathrm{f} \\
\mathrm{1} \mathrm{H}^{6} \cdot 7 \mathrm{~d} \\
\mathrm{I} \cdot 45 \mathrm{~d}, \mathrm{e}, \mathrm{f}\end{array}$ & $\begin{array}{l}\text { I } 52 \cdot 2 \mathrm{a}, \mathrm{b}, \mathrm{d} \\
7 \cdot 1 \mathrm{~d} \\
\text { I60.2 a, b, d } \\
23 \cdot 2 \mathrm{~d}\end{array}$ & $\begin{array}{c}\text { I } 44.7 \mathrm{a}, \mathrm{e} \\
7.0 \mathrm{e} \\
\mathrm{x} 53.0 \mathrm{a} \\
22.5 \mathrm{e}\end{array}$ & $\begin{array}{c}145.8 \mathrm{~b}, \mathrm{f} \\
7.4 \mathrm{f} \\
152.8 \mathrm{~b} \\
20 . \mathrm{ff}\end{array}$ & $\begin{array}{l}(7 \cdot 0) * 1 \cdot 7 \\
9 \cdot 1 \dagger \\
2 \cdot 1 \\
1 \cdot 8\end{array}$ \\
\hline
\end{tabular}

Means in the same row with the same notation are significantly different; a, b denote $P<0.05$, d, e, f, g denote $P<$ o.or.

* Values in parentheses are SE for the animals receiving $0.1 \mathrm{~g} \mathrm{Na}$ daily. Adjacent values refer to the $\mathrm{SE}$ for the remaining three groups of animals.

$\uparrow$ The analysis was of the logarithms of the concentration of $\mathrm{K}$ and the arithmetic means of $\mathrm{Na}, \mathrm{Na}$ plus $\mathrm{K}$ and the $\mathrm{Na}: \mathrm{K}$ ratio. Therefore, the sum of the mean $\mathrm{Na}$ plus the mean $\mathrm{K}$ does not equal the $\mathrm{Na}$ plus $\mathrm{K}$ value given, nor does the $\mathrm{Na}: \mathrm{K}$ ratio equal the mean $\mathrm{Na}$ divided by $\mathrm{K}$ value.

Table 5. Geometric means of the concentrations of sodium and potassium (m equiv./l) and the Na:K ratio and the arithmetic mean of the $\mathrm{Na}+\mathrm{K}$ concentration (m-equiv./l) in the ruminal fuid recovered at slaughter from steers given sorghum grain plus additional $\mathrm{Na}$ at three levels

\begin{tabular}{|c|c|c|c|c|c|}
\hline \multirow[b]{2}{*}{ Ion } & \multicolumn{4}{|c|}{$\mathrm{Na}$ intake $(\mathrm{g} / \mathrm{d})$} & \multirow[b]{2}{*}{$\% \mathrm{SE}$} \\
\hline & 0.1 & $3 \cdot 1$ & $6 \cdot 0$ & II 4 & \\
\hline $\mathrm{Na}$ & sId, e, f & I2od & $126 \mathrm{e}$ & $122 f$ & I I \\
\hline $\mathrm{K}$ & $48 \mathrm{~d}, \mathrm{e}, \mathrm{f}$ & $24 d$ & $27 \mathrm{e}$ & $23 f$ & 8 \\
\hline $\mathrm{Na}+\mathrm{K}$ & I07d, e,f & $147 \mathrm{~d}$ & $156 \mathrm{e}$ & $\mathrm{I} 45 \mathrm{f}$ & $9 *$ \\
\hline $\mathrm{Na}: \mathrm{K}$ & $\mathrm{I} \cdot \mathrm{Id}, \mathrm{e}, \mathrm{f}$ & $5 \cdot \mathrm{Id}$ & $4.7 \mathrm{e}$ & $5 \cdot 4 f$ & 13 \\
\hline
\end{tabular}

Means in the same row with the same notation are significantly different; d, e, f denote $P<0.01$.

* Average SE of the arithmetic mean. 
Plasma $\mathrm{Na}$ and $\mathrm{K}$. The concentrations of $\mathrm{Na}$ and $\mathrm{K}$ in the plasma sampled at $14 \mathrm{~d}$ intervals after the steers were first given the all-grain rations are presented in Tables 6 and 7. Although there were significant differences due to the $\mathrm{Na}$ treatments in the concentration of $\mathrm{Na}$ and $\mathrm{K}$ in the plasma on three sampling dates, the differences recorded were small and were not consistent.

Table 6. Concentration (m-equiv./l) of sodium in the plasma of steers given a basal ration of sorghum grain plus additional $\mathrm{Na}$ at three levels

\begin{tabular}{|c|c|c|c|c|c|}
\hline \multirow{2}{*}{$\begin{array}{l}\text { Days of } \\
\text { all-grain } \\
\text { feeding }\end{array}$} & \multicolumn{5}{|c|}{ Na intake $(\mathrm{g} / \mathrm{d})$} \\
\hline & 0.1 & $3 \cdot I$ & $6 \cdot 0$ & $\mathrm{II} \cdot 4$ & $\mathrm{SE}$ \\
\hline 14 & $141 \cdot 9$ & 144.9 & 145.5 & $141 \cdot 6$ & $\mathrm{I} \cdot 43$ \\
\hline 28 & $\mathrm{I} 4 \mathrm{I} \cdot 3$ & $14 x \cdot 3$ & 140.8 & 140.8 & 0.56 \\
\hline 42 & $143 \cdot 3$ & 143.8 & $144: 3$ & $144^{\circ} \mathrm{I}$ & 0.70 \\
\hline 56 & $142.7 \mathrm{~d}$ & $I 42 \cdot 5 \mathrm{e}$ & $\mathrm{I} 43 \cdot 4$ & $\mathrm{I} 44.6 \mathrm{~d}, \mathrm{e}$ & 0.44 \\
\hline 70 & $139.6 a$ & $137^{\circ} 6 \mathrm{a}, \mathrm{b}$ & $138 \cdot 6$ & $139.5 \mathrm{~b}$ & 0.57 \\
\hline 98 & 139.3 & $139 \cdot 3$ & 139.2 & 140.9 & 0.63 \\
\hline 128 & I 49.9 & 148.0 & 148.7 & 149.4 & $1 \cdot 56$ \\
\hline 139 & $140.5 \mathrm{a}, \mathrm{d}$ & I $39^{-8} 8 \mathrm{e}$ & I $38.7 \mathrm{a}, \mathrm{f}$ & $143^{\circ} \circ \mathrm{d}, \mathrm{e}, \mathrm{f}$ & 0.53 \\
\hline
\end{tabular}

Means in the same row with the same notation are significantly different; a, b denote $P<0.05$, d, e, f denote $P<0.01$.

Table 7. Concentration (m-equiv./l) of potassium in the plasma of steers given a basal ration of sorghum grain plus additional sodium at three levels

\begin{tabular}{|c|c|c|c|c|c|}
\hline \multirow{2}{*}{$\begin{array}{l}\text { Days of } \\
\text { all-grain } \\
\text { feeding }\end{array}$} & \multicolumn{5}{|c|}{$\mathrm{Na}$ intake $(\mathrm{g} / \mathrm{d})$} \\
\hline & $0 . x$ & $3 \cdot 1$ & $6 \cdot 0$ & II 4 & SE \\
\hline 14 & 5.0 & $4 \cdot 8$ & $5 \cdot I$ & $5 \cdot 0$ & 0.17 \\
\hline 28 & $4 \cdot 6$ & $4 \cdot 6$ & $4 \cdot 6$ & $4 \cdot 7$ & 0.09 \\
\hline 42 & $4 \cdot 9$ & $4 \cdot 8$ & $4 \cdot 8$ & 4.8 & 0.14 \\
\hline 56 & $4 \cdot 9 a$ & 47 & $4 \cdot 6 a$ & $4 \cdot 8$ & 0.08 \\
\hline 70 & $5 \circ \mathrm{d}, \mathrm{e}, \mathrm{f}$ & $4 \cdot 6 d$ & $4.4 \mathrm{e}$ & $4 \cdot 6 \mathrm{f}$ & 0.08 \\
\hline 98 & $4.9 \mathrm{~d}, \mathrm{e}, \mathrm{f}$ & $4 \cdot 4 d$ & $4.3 \mathrm{e}$ & $4 \cdot 2 \mathrm{f}$ & $0.1 \mathrm{I}$ \\
\hline I 28 & 4.7 & $4 \cdot 3$ & $4 \cdot 3$ & 4.5 & 0.15 \\
\hline I 39 & 4.4 & $4 \cdot 2$ & 40 & $4^{\cdot I}$ & 0.09 \\
\hline
\end{tabular}

Means in the same row with the same notation are significantly different; a denotes $P<0.05, \mathrm{~d}, \mathrm{e}, \mathrm{f}$ denote $P<0.01$.

Urinary concentration of $\mathrm{Na}$ and $K$. The mean concentration of $\mathrm{Na}$ in the urine was directly related to the level of dietary $\mathrm{Na}$ (Table 8), while the mean concentration of $\mathrm{K}$ was not significantly different for steers receiving the four levels of $\mathrm{Na}$.

Faecal concentration of $\mathrm{Na}$ and $\mathrm{K}$. The mean concentration of $\mathrm{Na}$ in the faeces of steers ingesting $0 . \mathrm{I} \mathrm{g} \mathrm{Na} / \mathrm{d}$ was $0.27 \pm 0.24 \mathrm{mg} / \mathrm{g}$ dry matter. This was significantly less than the means of $\mathrm{I} \cdot 38(P<0.01), \mathrm{I} \cdot 05(P<0.05)$ and $\mathrm{I} .63(P<0.00 \mathrm{I}) \mathrm{mg} / \mathrm{g}$ from steers ingesting either $3 \cdot \mathrm{I}, 6 \cdot 0$ or $\mathrm{II} \cdot 4 \mathrm{~g} \mathrm{Na} / \mathrm{d}$ respectively. There were no significant differences between the three groups receiving supplemental $\mathrm{Na}$. However, steers given coarsely rolled grain had a significantly lower $(P<0.05)$ concentration of $\mathrm{Na}$ in the faeces than steers given finely ground grain $\left(0 \cdot 79 v .1 \cdot 3^{8} \pm 0 \cdot 17 \mathrm{mg} / \mathrm{g}\right.$ ).

The intake of $\mathrm{Na}$ had no effect on the mean concentration of $\mathrm{K}$ in the faeces. The 
values were $5.7 \mathrm{I}, 4.33,3.90$ and $4.80 \pm 0.62 \mathrm{mg} / \mathrm{g}$ dry matter for the steers ingesting $0 \cdot \mathrm{I}, 3 \cdot \mathrm{I}, 6 \cdot 0$ and II $4 \mathrm{~g} \mathrm{Na} / \mathrm{d}$ respectively.

$E C F V$. Steers which were ingesting $6.0 \mathrm{~g} \mathrm{Na} / \mathrm{d}$ had a significantly greater $(P<0.05) \mathrm{ECFV}$ than those given the basal ration: $94.8 v .82 .8 \pm 2.81$ respectively. However, when the ECFV was expressed on a body-weight basis, these differences were no longer significant, the values being 267 and $279 \pm 8 \cdot \mathrm{Iml} / \mathrm{kg}$ for the steers given the basal diet and those ingesting $6.0 \mathrm{~g} \mathrm{Na} / \mathrm{d}$ respectively.

Table 8. Geometric means of the concentrations of sodium and potassium, of $\mathrm{Na}+\mathrm{K}$ (m-equiv. $\mid l$ ) and the Na:K ratio of the urine from steers given sorghum grain plus additional $\mathrm{Na}$ at three levels

\begin{tabular}{|c|c|c|c|c|c|}
\hline \multirow[b]{2}{*}{ Ion } & \multicolumn{4}{|c|}{$\mathrm{Na}$ intake $(\mathrm{g} / \mathrm{d})$} & \multirow[b]{2}{*}{$\% \mathrm{SE}$} \\
\hline & 0.1 & $3 \cdot 1$ & $6 \cdot 0$ & II.4 & \\
\hline $\begin{array}{c}\mathrm{Na} \\
\mathrm{K} \\
\mathrm{Na}+\mathrm{K} \\
\mathrm{Na}: \mathrm{K}\end{array}$ & $\begin{array}{l}2 \cdot 8 \mathrm{~d}, \mathrm{e}, \mathrm{f} \\
38 \cdot 6 \\
4 \mathrm{r} \cdot 2 \mathrm{a}, \mathrm{d} \\
0.09 \mathrm{~d}, \mathrm{e}, \mathrm{f}\end{array}$ & $\begin{array}{l}\text { I2.9 a, d, g } \\
40.8 \\
59.5 \mathrm{e} \\
0.48 \mathrm{a}, \mathrm{d}, \mathrm{g}\end{array}$ & $\begin{array}{l}22 \cdot 0 \mathrm{a}, \mathrm{b}, \mathrm{e} \\
39 \cdot 7 \\
69 \cdot 8 \mathrm{a}, \mathrm{b} \\
0.76 \mathrm{a}, \mathrm{e}\end{array}$ & $\begin{array}{c}38.8 \mathrm{~b}, \mathrm{f}, \mathrm{g} \\
60 . \mathrm{I} \\
1 \mathrm{I} 2.8 \mathrm{~b}, \mathrm{~d}, \mathrm{e} \\
0.89 \mathrm{f}, \mathrm{g}\end{array}$ & $\begin{array}{r}16 \cdot 6 \\
16 \cdot 8 \\
16 \cdot 8 \\
4.6\end{array}$ \\
\hline
\end{tabular}

Means in the same row with the same notation are significantly different; a, b denote $P<0.05, \mathrm{~d}, \mathrm{e}, \mathrm{f}, \mathrm{g}$ denote $P<0.01$.

Table 9. Weights of the adrenal and the parotid salivary glands and the widths of the zona glomerulosa and cortex of the adrenals from the steers given sodium at four levels

\begin{tabular}{|c|c|c|c|c|c|}
\hline \multirow[b]{2}{*}{ Measurement } & \multicolumn{5}{|c|}{$\mathrm{Na}$ intake $(\mathrm{g} / \mathrm{d})$} \\
\hline & $0 \cdot 1$ & $3 \cdot I$ & $6 \cdot 0$ & $\mathrm{II} \cdot 4$ & SE \\
\hline $\begin{array}{c}\text { Adrenal }(\mathrm{g}) \text { left } \\
\text { right } \\
\text { left }+ \text { right }\end{array}$ & $\begin{array}{l}8 \cdot 6 \\
8 \cdot 5 \mathrm{~d}\end{array}$ & $\begin{array}{l}8 \cdot 0 \\
7 \cdot 6\end{array}$ & $\begin{array}{l}8 \cdot 2 \\
8 \cdot 0 a\end{array}$ & $\begin{array}{l}7 \cdot 4 \\
6 \cdot 6 \mathrm{a}, \mathrm{d}\end{array}$ & $\begin{array}{l}0.38 \\
0.42\end{array}$ \\
\hline $\begin{array}{l}\text { left }+ \text { right } \\
\text { Width of adrenal cortex }\end{array}$ & $\begin{array}{l}17 \cdot 0 \\
31 \cdot 3 a, b, d\end{array}$ & $15 \cdot 7$ & $16 \cdot 0$ & 14.0 & 0.78 \\
\hline Width of zona glomerulosa* & $\begin{array}{r}3+3 \mathrm{a}, \mathrm{b}, \mathrm{d} \\
7 \cdot 6 \mathrm{~d}, \mathrm{e}, \mathrm{f}\end{array}$ & $\begin{array}{r}28 \cdot 5 \mathrm{a} \\
3 \cdot 8 \mathrm{~d}\end{array}$ & $\begin{array}{r}28 \cdot 4 b \\
3 \cdot 6 \mathrm{e}\end{array}$ & $\begin{array}{r}27 \cdot 8 \mathrm{~d} \\
3 \cdot \text { of }\end{array}$ & $\begin{array}{l}0.9 \\
0.5\end{array}$ \\
\hline $\begin{array}{l}\text { Width of zona glomerulosa as } \% \text { of } \\
\text { cortex }\end{array}$ & $24.0 \mathrm{~d}, \mathrm{e}, \mathrm{f}$ & $13.4 \mathrm{~d}$ & I3.0e & $10.9 \mathrm{f}$ & $1 \cdot 4$ \\
\hline $\begin{aligned} \text { Parotid: left }+ \text { right }(\mathrm{g}) & \\
& \text { left }+ \text { right }(\mathrm{g} / \mathrm{1} 00 \mathrm{~kg} \text { body-wt) }\end{aligned}$ & $\begin{array}{l}\text { I04.Id } \\
34 \cdot 2 \mathrm{~d}, \mathrm{e}, \mathrm{f}\end{array}$ & $\begin{array}{l}91 \cdot 4 \\
26 \cdot 8 \mathrm{a}, \mathrm{d}\end{array}$ & $\begin{array}{l}78 \cdot 7 \mathrm{~d}, \mathrm{e} \\
23 \cdot \mathrm{a}, \mathrm{b}, \mathrm{e}\end{array}$ & $\begin{array}{l}\text { I00.0e } \\
28 \cdot I \mathrm{~b}, \mathrm{f}\end{array}$ & $\begin{array}{l}5 \cdot 0 \\
1 \cdot 3\end{array}$ \\
\hline
\end{tabular}

Means in the same row with the same notation are significantly different; a, b denote $P<0.05$, d, e, f, g denote $P<0.0$.

* Arbitrary units.

Plasma $\mathrm{Cl}$, erythrocyte $\mathrm{Na}$ and $\mathrm{K}$, urea, inorganic phosphorus and haemoglobin concentration in the blood, and packed cell volume and hepatic vitamin $A$. Although significant differences existed between group means in the plasma $\mathrm{Cl}$ concentration in samples obtained on days 56, I 28 and 139 of all-grain feeding, these differences did not appear to be related to the intake of $\mathrm{Na}$ in the diet. The mean group erythrocytic $\mathrm{K}$ concentration was significantly higher in the steers ingesting II.4 $\mathrm{g} \mathrm{Na} / \mathrm{d}$ than in the other groups on all eight sampling dates. This difference was probably due to the initial distribution of the steers with erythrocytes of high and of low $\mathrm{K}$ content. None of the other blood constituents examined were found to be significantly affected by the treat- 
ments. The general means for the eight sampling periods were: plasma $\mathrm{Cl}, 100 \cdot \mathrm{I} \pm$ 0.ro m-equiv./1; erythrocyte $\mathrm{Na}, 74.8 \pm 0.46 \mathrm{~m}$-equiv./1; erythrocyte K, $25.5 \pm 0.21 \mathrm{~m}$ equiv./1; blood urea, $24.2 \pm 0.34 \mathrm{mg} / 100 \mathrm{ml}$; blood inorganic phosphorus, $5.8 \pm$ $0.04 \mathrm{mg} / 100 \mathrm{ml}$; haemoglobin, $12.9 \pm 0.05 \mathrm{~g} / \mathrm{100} \mathrm{ml}$; packed cell volume, $38.3 \pm$ $0.15 \%$ and red cell count, $6.75 \pm 0.032 \times 10^{6} / \mathrm{mm}^{3}$. The mean hepatic concentration of vitamin A at slaughter was $28 \cdot 2 \pm 4 \cdot 55 \mu \mathrm{g} / \mathrm{g}$ and was unaffected by treatments.

Adrenal and parotid salivary glands. The right adrenal glands from steers given the basal ration and from those ingesting $6 \mathrm{~g} \mathrm{Na} / \mathrm{d}$ were significantly heavier than from steers ingesting $\mathrm{I} \cdot 4 \mathrm{~g} \mathrm{Na} / \mathrm{d}$ (Table 9). The sum of the weights of both glands was not significantly affected by the $\mathrm{Na}$ treatment, although there appeared to be an inverse relationship between $\mathrm{Na}$ intake and gland weight.

The widths of the adrenal cortex and the zona glomerulosa as a percentage of the cortex were significantly greater in the adrenal glands from steers given the basal ration only, than in those from steers given additional $\mathrm{Na}$. When the weights of the parotid glands were expressed on a body-weight basis, the group given the basal ration had a significantly greater weight of parotid than those receiving extra Na. No histological differences due to the $\mathrm{Na}$ treatments were observed.

Histological examination of the adrenal showed that the greater width of cortex was due to hyperplasia of the zona glomerulosa and its invasion into the fasciculate zone.

Table to. Mean daily sodium and potassium balances of two steers, which had been ingesting a basal diet containing $0.003 \%$ Na for $166 \mathrm{~d}$. In period $A$, the balance was measured over $45 d$ when only the basal diet was given, whereas in period $B$ a supplement of sodium chloride was given to the steers

\begin{tabular}{|c|c|c|c|c|}
\hline \multirow[b]{2}{*}{ Measurement } & \multicolumn{2}{|c|}{$\mathrm{Na}$ (m-equiv./d) } & \multicolumn{2}{|c|}{$\mathrm{K}$ (m-equiv./d) } \\
\hline & Steer I & Steer 2 & Steer I & Steer 2 \\
\hline & & Period A & & \\
\hline Intake & $3 \cdot 49$ & $4 \cdot 14$ & 334 & 396 \\
\hline \multicolumn{5}{|l|}{ Excretion: } \\
\hline Urine & $1 \cdot 25$ & 0.75 & 288 & 227 \\
\hline Faeces & $2 \cdot 72$ & 3.03 & 23 & 103 \\
\hline Balance & -0.48 & 0.36 & 23 & 66 \\
\hline \multicolumn{5}{|c|}{ Period B } \\
\hline Intake & $385^{*}$ & $385^{*}$ & $43^{8}$ & $49 \mathrm{I}$ \\
\hline Excretion: & & & & \\
\hline Urine & $6 \cdot 6$ & $7 \cdot 9$ & $53^{8}$ & 266 \\
\hline Faeces & 3.0 & $8 \cdot 9$ & 82 & 233 \\
\hline Balance & 375 & $3^{68}$ & -182 & -8 \\
\hline
\end{tabular}

* 380 m-equiv. as sodium chloride, the remainder from the feed.

Kidneys and liver. The weight of the kidneys was not significantly affected by the treatments nor was the weight of the liver per unit body-weight. Histological examination of the kidneys did not reveal differences due to treatments.

$N a$ and $K$ balance. The two steers retained from the basal group and given the basal ration for a further period of $\mathrm{I} / 2 \mathrm{~d}$ showed no ill-effects due to the long period of $\mathrm{Na}$ 
deprivation. The mean daily intakes of feed and water by the two steers (designated as I and 2) during the three balance periods were 4.7 and $5.5 \mathrm{~kg}$ feed and 52 and $22 \mathrm{I}$ water respectively. Steer 2 consistently drank less water than steer $\mathrm{I}$.

The mean $\mathrm{Na}$ and $\mathrm{K}$ balances of the steers during these three periods while the basal diet was given and during the $16 \mathrm{~d}$ period of $\mathrm{Na}$ supplementation are shown in Table ro.

During the period in which the basal diet was given, the steers were essentially in $\mathrm{Na}$ equilibrium, but in positive $\mathrm{K}$ balance. When extra $\mathrm{Na}$ was supplied in period $\mathrm{B}$, there was a large positive daily $\mathrm{Na}$ balance and a negative $\mathrm{K}$ balance.

The mean daily feed intakes by steers I and 2 during the period of Na supplementation $(6 \cdot 1$ and $6.8 \mathrm{~kg})$ were greater than before Na supplementation, but the intakes of water ( 47 and 21 1) were similar.

\section{DISCUSSION}

The physiological adaptation of sheep to $\mathrm{Na}$ depletion and the role of aldosterone in the maintenance of $\mathrm{Na}$ equilibrium have been reviewed by Blair-West, Coghlan, Denton, Goding, Wintour \& Wright (1963) and Blair-West, Bott, Boyd, Coghlan, Denton, Goding, Weller, Wintour \& Wright (1965). Our observations show that the physiological adaptations to a dietary $\mathrm{Na}$ deficiency in steers are similar to those reported in sheep in which acute depletion of $\mathrm{Na}$ was induced by the loss of saliva from a parotid fistula.

A dietary deficiency of $\mathrm{Na}$ was evidenced in our steers fed on the basal ration by a depressed concentration of $\mathrm{Na}$ and an elevated concentration of $\mathrm{K}$ in the saliva and ruminal fluid (low $\mathrm{Na}: \mathrm{K}$ ratio), by hyperplasia of the zona glomerulosa of the adrenal cortex, and by a reduced feed intake and growth rate. Steers ingesting $3^{\cdot} \cdot \mathrm{I} g$ or more $\mathrm{Na} / \mathrm{d}$ produced saliva with a Na:K ratio similar to that reported by Bailey \& Balch (196r), Bott, Denton, Goding \& Sabine (1964), Kemp \& Geurink (1966) and Kemp (1966) for Na-replete cattle. However, bovine saliva in our Na-replete animals appeared to contain a slightly lower concentration of $\mathrm{Na}$ than the $160-\mathrm{I} 80 \mathrm{~m}$-equiv./1 reported by Blair-West et al. (1965) for sheep and goats.

Aldosterone produced by the adrenal cortex is the pivotal adjusting mechanism for $\mathrm{Na}$ conservation in the urine, faeces, sweat and salivary secretions of the ruminant (Blair-West $e t$ al. 1965 ). As there is a causal connexion between the fall in the salivary $\mathrm{Na}: \mathrm{K}$ ratio and aldosterone secretion (Blair-West et al. 1963; Blair-West, Coghlan, Denton, Goding \& Wright, 1964), the adrenal glands of the steers given the basal ration should have produced more aldosterone than those ingesting $3^{\cdot}$ I $g$ or more $\mathrm{Na} / \mathrm{d}$. The hyperplastic zona glomerulosa of the adrenals from steers given the basal ration provides supporting evidence of a greater aldosterone production by these steers than by those receiving the $\mathrm{Na}$ supplements.

As the mean Na: $\mathrm{K}$ ratio of the saliva from steers given the basal ration did not substantially decrease after the first sampling at $56 \mathrm{~d}$, it would appear that either the level of aldosterone secretion was the same at $5^{6}$ as at $140 \mathrm{~d}$, or that the effect of aldosterone upon the salivary gland in substituting $\mathrm{K}$ for $\mathrm{Na}$ was maximal at $5^{6} \mathrm{~d}$. The low concentration of $\mathrm{Na}$ in the urine from steers given the basal ration is evidence 
that urinary loss of $\mathrm{Na}$ by this route was much less than in steers given the $\mathrm{Na}$ supplements.

Bailey (I96r) found that in cows the concentration of $\mathrm{Na}$ in the ruminal fluid was related to that in the saliva, but the former did not fall below $60 \mathrm{~m}$-equiv./l. However, we found a mean value of $50.7 \mathrm{~m}$-equiv. $\mathrm{Na} / \mathrm{l}$ in the ruminal fluid of steers receiving only $0.1 \mathrm{~g} \mathrm{Na} / \mathrm{d}$, and individual values were as low as $20 \mathrm{~m}$-equiv./l.

Although steers given the basal ration were ingesting only $0.1 \mathrm{~g} \mathrm{Na} / \mathrm{d}$, the concentrations of $\mathrm{Na}, \mathrm{K}$, and $\mathrm{Cl}$ in the plasma remained remarkably constant. A decrease in the concentration of $\mathrm{Na}$ and an increase in the concentration of $\mathrm{K}$ in the plasma is one mechanism for the control of aldosterone secretion, but other factors of humoral origin are also involved (Blair-West et al. 1963). Our finding of a constant concentration of $\mathrm{Na}$ in the plasma, after a fairly long period of feeding on a low-Na diet, is in accord with previous reports that plasma concentrations of $\mathrm{Na}$ and $\mathrm{K}$ are of little diagnostic value in the detection of Na deficiency (Kemp \& Geurink, 1966; Underwood, ig66).

The restricted intake of $\mathrm{Na}$ by the steers given the basal ration apparently was insufficient to cause a gross disturbance in water metabolism, as neither the daily intake of water nor the ECFV per unit body-weight was significantly different from those of steers given Na supplements.

In two experiments in which high-grain rations were given to steers kept in pens we found no response in growth rate to a supplement of sodium chloride (Morris, Gartner \& Pepper, 1967; Morris, Pepper \& Gartner, I969). In the first experiment $10 \%$ roughage was included in the feed, which presumably provided adequate $\mathrm{Na}$, whereas in the second experiment only a limited number of steers received all-grain rations. There may be many similar, but unpublished experiments in which no growth responses were obtained to supplements of sodium chloride.

There are very few reports of a growth response in ruminants to sodium chloride. Boussingault (I 847) reported 'l'influence du sel ajouté à la ration n'a pu être suffisamment appréciée dans ses effets sur la croissance du bétail.' Walker (1957) presented results which he suggested showed a growth response in grazing cattle in Rhodesia to a sodium chloride supplement. However, growth responses were reported to a supplement of $28 \mathrm{~g}$ salt/animal daily but not from $5^{6} \mathrm{~g}$ salt/animal daily. McClymont, Wynne, Briggs \& Franklin (1957) reported a growth response to sodium chloride in sheep given high-grain rations after a long period of undernutrition. In their second experiment they showed that the effect was due to $\mathrm{Na}$ rather than to $\mathrm{Cl}$. The results of our experiment show an unequivocal growth response in cattle to a supplement of $\mathrm{Na}$. The significant growth response resulting from $\mathrm{Na}$ supplementation was accompanied by a significantly greater intake of feed, which would indicate that the growth retardation from $\mathrm{Na}$ deficiency may be due to inappetence.

Although quantitative estimations have been made of the $\mathrm{Na}$ requirement for growth of pigs (Meyer, Grummer, Phillips \& Bohstedt, 1950) and poultry (Burns, Cravens \& Phillips, r953), this information is not available for cattle. As the requirements of the lactating cow for $\mathrm{Na}$ are quantitatively greater than those of the growing animal, they have been investigated by a number of workers. The Agricultural 
Research Council ( 1965 ) indirectly estimated the dietary requirements for the maintenance of cattle from balance results derived from dairy cows and estimates of inevitable losses. However, the regressions of $\mathrm{Na}$ balance on $\mathrm{Na}$ intake minus $\mathrm{Na}$ excretion in milk show considerable variation around the point of zero balance. Also, because of the ability of the ruminant's intestine to control Na loss (Renkema, Senshu, Gaillard \& Brouwer, 1962), and because of the variation in faecal output due to different rations, the calculation of inevitable losses by this method may incur serious errors.

Our balance trial results demonstrate that cattle under conditions of prolonged $\mathrm{Na}$ deprivation can reduce the renal loss of $\mathrm{Na}$ to about $\mathrm{r} \mathrm{m}$-equiv./ $\mathrm{d}$ and the faecal loss to about three times this quantity. The faecal losses which we recorded are considerably less than the values computed by the Agricultural Research Council (1965) to estimate maintenance requirements. It was apparent that, during $\mathrm{Na}$ deprivation, $\mathrm{K}$ substituted extensively for $\mathrm{Na}$ in body fluids, such as the saliva and the ruminal fluid. The effect of this was demonstrated by the positive $\mathrm{K}$ balance of both steers during the prolonged period of $\mathrm{Na}$ depletion and the negative $\mathrm{K}$ balance, especially in one steer, on $\mathrm{Na}$ repletion.

A consideration of our results relating to the $\mathrm{Na}: \mathrm{K}$ ratio of the saliva and the ruminal fluid, the width of the zona glomerulosa, and the daily feed intake and growth rate, suggest that the daily $\mathrm{Na}$ requirements for growth of steers of between 200 and $300 \mathrm{~kg}$ body-weight and gaining $0.9 \mathrm{~kg} / \mathrm{d}$ lies between $133 \mathrm{mg}$ (deficient) and $3 . \mathrm{I} \mathrm{g} /$ head (adequate). This allowance is considerably less than that suggested by the Agricultural Research Council (1965) of about $5.5 \mathrm{~g}$, or by the National Research Council (1963) of $0.5 \%$ of sodium chloride in high-grain rations.

We wish to thank The Australian Meat Research Committee for generous financial assistance under Project DAQ 25, The Southern Electric Authority, Tennyson Power House for the donation of the large quantity of demineralized water used in the experiment, Miss Patricia M. Pepper for statistical analyses, Mr K. Schultz for the preparation of the histological material, Mr M. J. Radel for care of the experimental animals and Miss Jane Dalby, Mr J. Connel and Mr D. Utting for technical assistance.

\section{REFERENCES}

Agricultural Research Council (1965). The Nutrient Requirements of Farm Livestock. No. 2. Ruminants, Technical Reviews and Summaries. London: H. M. Stationery Office.

Aines, P. D. \& Smith, S. E. (1957). F. Dairy Sci. 40, 682.

Association of Official Agricultural Chemists (1960). Official Methods of Analysis 9th ed. Washington, DC: Association of Official Agricultural Chemists.

Babcock, S. M. (1905). Ann. Rep. Wis. agric. Exp. Stn p. 129.

Bailey, C. B. (г961). Br. F. Nutr. 15, 489 .

Bailey, C. B. \& Balch, C. C. (I96I). Br. F. Nutr. 15, 383.

Blair-West, J. R., Bott, E., Boyd, G. W., Coghlan, J. P., Denton, D. A., Goding, J. R., Weller, S., Wintour, M. \& Wright, R. D. (1965). In Physiology of Digestion in the Ruminant p. I98 [R. W. Dougherty, editor]. Washington: Butterworths.

Blair-West, J. R., Coghlan, J. P., Denton, D. A., Goding, J. R., Wintour, M. \& Wright, R. D. (1963). Recent Prog. Horm. Res. 19, $31 \mathrm{I}$. 
Blair-West, J. R., Coghlan, J. P., Denton, D. A., Goding, J. R. \& Wright, R. D. (1964). In Salivary Glands and their Secretions p. 253 [L. M. Sreebny and Julia Meyer, editors]. New York: Pergamon Press.

Bott, E., Denton, D. A., Goding, J. R. \& Sabine, J. R. (1964). Nature, Lond. 202, 46r.

Boussingault, J. B. (1847). C. r. hebd. Séanc. Acad. Sci., Paris 25, 729.

Bowler, R. G. (1944). Biochem. F. 38, 385 .

Burns, C. H., Cravens, W. W. \& Phillips, P. H. (1953). F. Nutr. 5o, 3 I7.

Conns, I. (1957). Biometrics 13, 387 .

Donaldson, R., Sisson, R. B., King, E. J., Wootton, I. D. P. \& Macfarlane, R. G. (I95 I). Lancet 26o, 874.

Gartner, R. J. W. \& Ryley, J. W. (1956). Qd F. agric. Sci. 13, I.

Gartner, R. J. W. \& Twist, J. O. (1968). Aust. J. exp. Agric. Anim. Husb. 8, 210.

Kemp, A. (1966). Proc. int. Grassld Congr. x. Helsinki, Finland p. $4 \mathrm{Ir}$.

Kemp, A. \& Geurink, J. H. (I966). Tijdschr. Diergeneesk. 9r, 580 .

Levine, J. M., Leon, R. \& Steigmann, F. (1961). Clin. Chem. 1, 488.

McClymont, G. L., Wynne, K. N., Briggs, P. K. \& Franklin, M. C. (1957). Aust. F. agric. Res. 8, 83.

Meyer, J. H., Grummer, R. H., Phillips, R. H. \& Bohstedt, G. (1950). J. Anim. Sci. 9, 300.

Moir, K. W. (1954). Qd F. agric. Sci. II, I43.

Morris, J. G. \& Gartner, R. J. W. (1967). F. agric. Sci., Camb. 68, I.

Morris, J. G., Gartner, R. J. W. \& Pepper, P. M. (1967). Aust. Y. exp. Agric. Anim. Husb. 7, I44.

Morris, J. G. \& O'Bryan, M. S. (1965). F. agric. Sci., Camb. 64, 343 .

Morris, J. G. \& Pepper, P. M. (1969). F. agric. Sci., Camb. 73, 41.

Morris, J. G., Pepper, P. M. \& Gartner, R. J. W. (1969). Aust. F. exp. Agric. Anim. Husb. 9, 57.

National Research Council (1963). Publs natn. Res. Coun., Wash. no. I137.

Renkema, J. A., Senshu, T., Gaillard, B. D. E. \& Brouwer, E. (1962). Nature, Land. 195, $3^{89 .}$

Theiler, A., Green, H. H. \& Du Toit, P. J. (1927). F. agric. Sci., Camb. 17, 29 I.

Underwood, E. J. (1966). The Mineral Nutrition of Livestock. Food and Agriculture Organization of the United Nations, Commonwealth Agricultural Bureaux. Central Press (Aberdeen) Ltd.

Walker, C. A. (1957). F. agric. Sci., Camb. 49, 394. 